\title{
Evolution of a Life Sentence James Ruston
}

\section{INTRODUCTION}

Since 1989, I have served a life sentence. At the age of seventeen, two high school friends and I attempted to render a robbery victim unconscious and steal his car; however, one co-accused struck the victim repeatedly, with force enough to cause death. I was transferred from Young Offender to Adult Court and sentenced to Life with no parole eligibility for 25 years. On appeal, in 1997, my parole eligibility was reduced to seven years which made me immediately eligible. So far, I have been incarcerated for almost twenty-six of the past thirty years of this sentence. In this article, I will describe these many years of incarceration, the struggles I have had with parole and returns to prison. Using my case as an example, I will argue that using a 'one-size fits all' approach, the system fails and creates harm rather than reducing it.

\section{LOOKING BACK}

My teenaged offence participation is a mortifying regret, counter to my values and my normal behaviour and abruptly ended my immature criminal ideations. I, alone, am culpable for my actions and their impact which resonates through my community. I was fairly convicted and sentenced for my part in taking an innocent life. My guilt inspires penance in a lifelong commitment to positive change through personal growth, contribution to community, and meaningful relationships. My values have evolved, through interaction with and learning from family, friends, and some CSC staff and employees. I am particularly grateful to a group of inspiring educators who taught me in the pre-trial young offenders education program; Ken Ashcroft, Pat Bossert, Dave Elliot, and Mike Campure, fostered a positive attitude during two years of high school courses and my graduation before I transferred to the adult correctional system. ${ }^{1}$

The adult system was in stark contrast to my other institutional inexperience, or any experience in the free world. I was unprepared for the wildly dysfunctional Collins Bay Institution, often referred to in those days as Gladiator School. ${ }^{2}$ I was still a teenager when I arrived, and fear, guilt, family support, and desire for self-improvement diverted me from most of the violent, drug-saturated culture. Instead, I engaged with teachers, 
clergy, psychologists, and groups with community volunteers, and anyone willing to help. I cherished visits from loving family (parents, grandparents, siblings, aunts, cousins) and friends, who travelled several hours to visit regularly. There is much research that indicates that these visits are critical components in my ability to reintegrate after prison as they facilitate contacts, a sense of individual worth, help maintain hope, provide direction and reduce recidivism (Bales and Mears, 2008; De Claire and Dixon, 2017; Dixey and Woodall, 2012; Monahan et al., 2011; Munn and Bruckert, 2014).

Despite my efforts, my social development delayed and this is a phenomenon common among long term prisoners (Jewkes, 2005). I see it in many serving lengthy prison sentences; as time and resources wear down, so do people, prisoners and staff alike. ${ }^{3}$ Prior to my successful appeal, at about year five of my life sentence, I succumbed to the pressures by finding relief in substance use. Experimenting in the prevalent subculture, I came to rely mostly on marijuana, until an accumulation of positive urinalysis tests challenged me to develop alternative institutional coping strategies. Supports helped me challenge personal and social habits to develop a healthier life balance. I learned to insulate myself from the sub-culture I had, unwittingly, become part of, and eventually quit recreational substance use to earn day parole in 2007. Unfortunately, despite 30 years of ongoing treatment and punishment, complete abstinence from alcohol, in the community substance use has become a frustrating snag.

\section{ALCOHOL USE AND DAY PAROLE}

The Parole Board of Canada has the right to impose 'special conditions' on those who are granted conditional release. In my case, I was told that I could not consume any alcohol. I have never understood this condition as it seems to go against cultural norms and limits social connection - two things that are difficult for someone with a long history of captivity to relearn. Nearly $80 \%$ of Canadians consume alcohol, making it an integral cultural pastime and a way for a single person with many years of longing for commonly shared social experience to find it (Health Canada, 2008). My frame of reference for moderate alcohol use is built on pleasant, joyful memories of quaint family gatherings, weekends at the cottage, dating, and dinner parties. Having a couple of drinks tends to ease connection with others, in routine social situations with new co-workers and friends. Further, 
alcohol use is not a consequence of my sentence, nor a risk factor in my case; there is no lawful justification to impose the condition. In fact, three previous, consecutive Parole Boards cancelled very similar suspensions, when they also determined that my alcohol use did not pose an undue risk. The zero-tolerance approach to my use of alcohol has resulted in repeat parole suspensions and revocation. I am re-released, months or years later, six times over the past twelve years. In almost every case, ${ }^{4}$ my suspensions were the result of random alcohol-positive urine tests.

Being returned to prison for a behaviour that is legal in Canada is not unique to my situation. Research shows that most day parole revocations are for violations of parole terms and not for new crimes. In 2018-2019, of the 3619 people on day parole, 304 were revoked for breach of conditions and this can include curfew, contact and substance use conditions (Public Safety, 2019).

During my last release, on September $14^{\text {th }}$, 2017, a search of my backpack revealed a partial bottle of alcohol. The violation led to my day parole being suspended, however, the CSC Psychologist alerted Ottawa Parole to factual errors in the ensuing Assessment for Decision Report. Neglecting the email request for corrections, the Community Parole Officer requested an updated Psychological Risk Assessment. The request was denied, due to the existence of a valid Assessment. Instead, the parole officer reported a personal opinion of risk, neglecting to consider the existing Psychological Risk Assessments or the considerable weight of my crime-free lifestyle. Since the threshold for parole revocation is "undue" elevation of risk, at the subsequent hearing, the Parole Board postponed, and ordered an updated CSC Psychological Risk Assessment - specifically addressing my alcohol use.

Four months later, the 24-page report confirmed a diagnosis of a non-risk related, "Alcohol Use Disorder - Mild," and reaffirmed that my risk was manageable in the community. Despite this, at the reconvened hearing, the Parole Board of Canada followed the Parole Officer's mislead and ignored the risk assessment. In their written decision, erroneous information was included along with a disparaging misquote from the Psychologist's Report that obfuscates the professional risk opinion. Despite errors, the Appeal Board upheld the revocation with a contradiction: "While the Psychological [Risk] Assessment Report dated February 20, 2018 states that there is no evidence that your current pattern of alcohol use increases your risk of violence, and that your current risk could be managed in the community 
Table 1: Transfers - James Rushton (1989-2020)

\begin{tabular}{|c|c|c|}
\hline INSTITUTION & DATE & REASON \\
\hline $\begin{array}{l}\text { Port Coquitlam YO } \\
\text { Detention Centre }\end{array}$ & October 25, 1989 & Arrest \\
\hline $\begin{array}{l}\text { Hamilton Wentworth YO } \\
\text { Detention Centre }\end{array}$ & 1989-1991 & Transfer \\
\hline $\begin{array}{l}\text { Hamilton Wentworth } \\
\text { Detention Centre }\end{array}$ & $1991,2014,2015$ & Transfer, Suspension x 2 \\
\hline $\begin{array}{l}\text { Toronto West Detention } \\
\text { Centre }\end{array}$ & 1991 & Transfer \\
\hline Maplehurst Detention Centre & 1991-1992, 2011, 2015 & Transfer, Suspension x 2 \\
\hline $\begin{array}{l}\text { Toronto East Detention } \\
\text { Centre }\end{array}$ & $1992,2011,2014$ & Transfer x 3 \\
\hline Don Jail & 1992,2011 & Transfer x 2 \\
\hline $\begin{array}{l}\text { Millhaven Penitentiary } \\
\text { Assessment Unit }\end{array}$ & 1992,1999 & Transfer x 2 \\
\hline Collins Bay Institution & 1992-1998 & Pen Placement \\
\hline Bever Creek Institution & 1998-2002 & Transfer \\
\hline Fenbrook Institution & 1998,2002 & Transfer $\mathrm{x} 2$ \\
\hline Sudbury Detention Centre & 1998,1999 & Transfer x 2 \\
\hline Northern Treatment Centre & 1998-1999 & Treatment Program \\
\hline Bath Institution & $\begin{array}{l}\text { 2002-2004, 2011, 2017- } \\
2021\end{array}$ & Transfer x 4 \\
\hline Frontenac Institution & $\begin{array}{l}\text { 2004-2006, 2007, } 2008 \\
-2010\end{array}$ & Transfer x 3 \\
\hline Maison Decision House CRF & $2006,2013,2016,2017$ & Treatment Program x 4 \\
\hline Kirkpatrick CRF & 2007, 2016-2017 & Transfer x 2 \\
\hline $\begin{array}{l}\text { Ottawa Carleton Detention } \\
\text { Centre }\end{array}$ & 2007,2017 & Suspension $\mathrm{x} 2$ \\
\hline $\begin{array}{l}\text { Kingston Penitentiary } \\
\text { Temporary Detention }\end{array}$ & 2007,2011 & Transfer x 2 \\
\hline $\begin{array}{l}\text { St, Leonard's Emerald St. } \\
\text { CRF }\end{array}$ & $\begin{array}{l}\text { 2010-2011, 2013-2014, } \\
2015\end{array}$ & Transfer x 3 \\
\hline $\begin{array}{l}\text { Stonehenge Therapeutic } \\
\text { Community }\end{array}$ & 2011,2012 & Treatment Program \\
\hline Pittsburg Institution & 2011-2014 & Transfer x 2 \\
\hline Joyceville Institution & $2013,2014-2017$ & Transfer x 3 \\
\hline
\end{tabular}


without such a condition, the Board has the discretion to impose the special condition as long as it is reasonable and necessary". The decision to revoke and the special condition itself, is not premised on substantive evidence of risk, and are therefore without reasonable purpose, or effect; they are incommensurate with risk or need, and are both unreasonable and unnecessary. Misrepresenting and disregarding relevant facts compromises decision-making guidelines, and violates, among others, section 24 (1) of the Corrections and Conditional Release Act (CCRA) by failing to, “...take all reasonable steps to ensure that any information about an offender that it uses is as accurate, up to date and complete as possible".

According to multiple CSC Psychological Risk Assessments, I am a nonviolent, non-criminal personality type, a manageable risk, safe to release, "with or without a drinking condition". Actuarial tools measure my current risk as, "slightly decreased", undercutting previous assessments that also endorsed manageable risk and safe conditional release, due to my absence of criminal or violent behaviour and, indirectly, the uneventful nature of my alcohol use. In other words, despite ongoing suspensions for alcohol use, my risk is decreasing. These examples illustrate how risk knowledges continue to create life barriers and impediments to criminalized people (also see Maurutto and Hannah-Moffat, 2006).

The comprehensive report proposes a harm reduction strategy to address the mild alcohol use disorder and explicitly discourages parole supervisors from suspending for non-risk related issues because it is impeding reintegration. In my experience, current parole authorities ignore mental health professionals and their compilation of independent, valid assessments.

\section{THE IMPLICATIONS OF PAROLE REVOCATIONS FOR A LIFER}

The Charter of Rights suggests justice is dispassionate. Yet, it appears that angry reactions to my failure to adapt to the 'one-size fits all' release plan is inflating fears, obfuscating the professional psychological risk assessments and replacing them with expertise that neither parole officers nor the parole board members possess. Subverting professional opinions abuses the process, and prevents addressing the "mild", manageable, community capacity issue at enormous human and financial costs. I am embarrassed 
by and humiliated that my common foible continues to be catastrophically criminalized and the subject of shaming by authorities who then commonly mention drinking in their leisure. It is a frustrating irony to have attended Alcoholics Anonymous meetings and other self-help groups for many years in prison, in search of positive social interaction amidst the predominantly negative atmosphere, long before my use of alcohol in the community.

Also humiliating is the never-ending culmination of traumatic prison experiences which has resulted in more than one suicide attempt in recent years. Two of these followed parole suspensions. These desperate events are met with punishment, unhealthy doses of solitary confinement, and revocation (overturned on appeal, a year later). They are conflating mental health issues with criminal risk. Their 'help' equates to exhaustive prison punishment which drains hopes and ambitions while I resist disparaging institutional realities. Community reintegration is held up in these circumstances like a carrot. It is arbitrarily withheld, adding despair to create a twisted game of survival. Back in 2011, the Office of the Correctional Investigator noted that the suicide rate "is 6 times higher" than that in the Canadian population. More recently, the 2019 Corrections and Conditional Release Statistical Overview confirmed the magnitude of the problem when they noted that "the suicide rate was approximately 55 per 100,000 for incarcerated federal offenders, and approximately 36 per 100,000 for incarcerated provincial offenders. These rates are significantly higher than the 2009 rate of 11.5 suicides per 100,000 people in Canada" (Public Safety Canada, 2019). Not surprisingly, the government's own reports show that one of the main predictors of who will commit suicide is the presence of an indeterminate sentence like mine (CSC, 2017). I cannot help but feel like a square peg crumbling under the boot-heel of Corrections, as it relentlessly stomps me into its dark and empty round hole, potentially, out of existence.

Usually, only the extreme cases of neglect and abuse receive attention, too often and too late. Nearly twelve years ago, a handful of corrections staff stood watching the in-custody suicide of Ashley Smith, an abhorrent abuse of human rights (Sapers, 2008). In the more recent case, charges against Adam Capay for a fatal stabbing of another prisoner, were stayed when the disparaging institutional conditions he experienced were revealed (Parkes, 2017). In an act of cruel and unusual punishment, Mr. Capay was essentially forgotten for 1,647 days in solitary confinement (Wildeman, 2020). Justice John Fregeau categorized the experience as "prolonged, egregious and 
intolerable... proforma, perfunctory and meaningless" (White, 2019), increasingly familiar language used by Judges describing CSC's treatment of prisoners. Institutional traumas, both subtle and extreme, too easily violate prisoners' human rights. Compassion and reason, and in my case, the CCRA and the Charter, are simply ignored.

The façade of an internal grievance system cannot keep up with the constant stream of policy violations, a notoriously ineffective process, as defendants work on their own complaints. More than one investigator has called for shifts in how prisoners' grievances are handled. Indeed, more than twenty years ago, the former Correctional Investigator (1996) wrote: "I believe there is a need for a mechanism between this office and the courts with the authority to order timely corrective action in instances of illegalities, gross mismanagement or unfairness. The correctional environment, the impact of administrative decisions on individuals within that environment and the consistent failure of the Correctional Service to approach individual and systemic areas of concern in an objective, thorough and timely fashion demands that a timely and responsive binding avenue of redress be available" (p. 2). With prisoners securely disconnected from society, hidden behind concrete and steel (and the 'blue wall'), accountability for violations is easily sidestepped with specious narratives, controlled by $\mathrm{CSC}$, free from valid third-party oversight. In my experience, prisoners are defenseless against antiquated, adversarial attitudes resistant to changes and rehabilitative progress.

As former Minister of Public Safety and Emergency Preparedness, the Honorable Ralph Goodale announced that "immense changes" would be underway within CSC as part of Trudeau's Liberal government. That was years ago. "Immense changes" require a philosophical change, not just more staff and more security. More and more research reveals that prisons don't make societies safer, prisons are dysfunctional colleges consolidating prisoners, most of whom have histories of trauma, neglect, and or abuse. We exist in a state which is socially stagnant, highly stressful, full of abnormal deprivation, and where efforts to change are mired in negative influences in intensely punishing conditions. Those prisoners who do manage to change - for the better - do so in spite of negative prison influences, not because of them. Many, like Ashley Smith and Adam Capay, remain hidden behind the walls, fighting for survival, at least until post mortem investigations lead to public enquiries and damning certified civil court actions. 
People who work for the system know this too. Just ask Robert Clark (2017), former Deputy Warden, and fellow 30-year CSC veteran. His insightful career memoir, Down Inside, follows much of my journey, through several Federal Institutions, but from an administrative point of view. He estimates, in his relevant experience as a trusted investigative troubleshooter, that 70 percent of CSC staff is either incompetent or corrupt. Moral conflict, amidst an unhelpful Conservative (Stephen Harper) government, led to his early retirement, in 2009.

In addition to my family, there have been a handful of people (teachers, psychologists, staff and fellow prisoners) who continue to help. At one point, several years ago, one institutional psychologist suggested discontinuing counselling. He said he'd never seen anyone with as much counselling; normally, psychology staff resources are reserved for prisoners with 'high needs'. ${ }^{5}$ Having exhausted most relevant institutional resources, I recently returned to A.A. meetings, on the advice of my Institutional Parole Officer. I was seeking to cultivate perspective that might help me to internalize the zero-tolerance lifestyle more completely. Though there is a welcoming and friendly atmosphere, tales of fighting, days-long benders, and the many other alcohol-induced reactions do not resonate with my own experience. It feels awkwardly disingenuous, and sometimes depressing; this was the reason I stopped attending years ago. To avoid the legal, social, and health risks, I have always chosen to live without alcohol in prison. I stopped using illicit drugs, about twelve years ago for similar reasons. Over twenty years ago and long before a lawsuit forced CSC to ban tobacco, I quit smoking when I first earned my Personal Fitness Trainer certification. I don't seem to have an addictive personality.

I encounter a wide variety of perspectives, reactions, and advice from CSC Staff, and among a Canadian culture that promotes and encourages alcohol use. I cannot help but wonder if those with the strongest reactions to my mild alcohol issue have their own personal issue with it. Those who know me, like family and friends, were consulted in a recent CSC Risk Assessment and expressed their opinion of my alcohol use as safe, and are unconcerned if the condition is removed.

Years of programming, counselling, challenging and re-challenging thinking in self-reflection, has taught me a plethora of skills and tools to exercise, some daily. A proponent of mindful meditation, my experience has also been sometimes confusing, a seemingly endless rabbit hole of 
wide ranging, pseudo-professional advice, loaded language, and personal bias, rather than science or law. Keeping me in prison, for example, where I initially developed a drug problem, to address a mild alcohol use disorder experienced in the community, seems excessive and counterintuitive. Imprisonment, at this late stage of my sentence, feels like a wasteful and destructive alternative to rehabilitation. Regardless, I am approaching the struggle as a learning experience and remain open to help along my way while adding meaning to my life by contributing to others' education, health and fitness, recovery, and release planning. I enjoy writing letters and memoirs, cooking, reading, and am currently learning to play guitar in my leisure. Physically, I am surviving, despite constant loneliness and longing for stable, meaningful relationships, and ordinary human contact and experience, beyond the forced, transient prison relations and authoritarian subservience. It is increasingly difficult to build and maintain long-term relationships amidst a perpetually fractured, drastically uprooted endless correctional existence. ${ }^{6}$ Losing these nascent community connections upon repeated suspension is painfully discouraging. I feel increasingly skittish investing in new relationships for fear of losing them too.

The clumsiness of my reintegration efforts reveals my imperfect self, a work in progress. Thankfully, support and maturity cultivate curiosity and openness to growth and learning opportunities. Even pains of imprisonment inspire empathy for others. At the same time, however, I fear the emotionally abrasive experience is hardening me, narrowing my perspective, and making it more difficult to navigate and to trust. I worry that my narcissistic, defensive tendencies are reinforced by the threatening experience, and though probably also responsible for my survival of prison, underlie my alcohol rationalizations, and will continue to elicit disdain and punishment from less-sympathetic authorities - despite the calculated absence of risk. Notwithstanding my mild alcohol use disorder, I am usually more reticent and not only routinely acquiescent to authority, but am self-motivated in my personal recovery and development. Borrowing study material from psychology, I continue challenging my alcohol rationalizations, broadening what I can of my perspective, even in the familiar face of despair of indefinite imprisonment, as connections to loved ones painfully diminish in the yearslong relationship distances, evoking bouts of depression and social anxiety reminiscent of childhood loss. I continue to exercise mindfulness, using Acceptance and Commitment Therapy (ACT) as of late, to more effectively 
embrace difficult circumstance and the emotions they evoke, while linking the abstinence choice in the community to my goals of redemption, and the value of my community relationships. I also cannot help feeling exhausted by the forty-eight moves through the system in thirty years, drastically disconnected from stable humane development: From one cage to another, identity, relationships, and life purpose are constantly uprooted and ground down by the heavy, relentless, institutional machinery. The terrible journey is then conflated with an already opprobrious identity, however historical. Partisan politicians and media demagogues sensationalize disparaging prisoner stereotypes using gross generalizations to exploit irrational fears and prejudice to provoke a less-informed public into short-sighted, hateinfused agendas that undermine community confidence in our criminal justice system and the penitent prisoners whose core identities as citizens, neighbors, mothers, fathers, children, brothers, sisters, grandparents, cousins, aunts and uncles are all but forgotten. Those who survive the traumatic prison experience are in need of help to heal and reclaim healthy core identities. Poisoning the reconciliation and rehabilitation process with vitriolic, self-aggrandizing discourse looks and feels, from my view, an awful lot like bullying those who are likely in the most vulnerable time and place of our lives, without protections of privilege. People cannot be helped up while they are being stepped on by others to get ahead.

\section{FRACTURED RELATIONSHIPS}

I wait for the next in an endless line-up of random strangers to review my lengthy, overgrown case; it is unlikely anyone reads my extensive 30-year-old file anymore. Parole authorities wield near absolute power to broadly interpret subjective narratives, and arbitrarily condemn prisoners to added years of unnecessary conditions and 'warehousing' without meaningful purpose or attention, long after parole eligibility dates have passed. I still recall, at 19 years old, the words of the guard transferring me from the detention centre to the federal system: "Happy hunting". My fear of predators has since shifted, entirely, from fellow prisoners to system driven operators.

My supports and I labour through the endless challenge, intent on establishing stable roots in the community. While re-incarcerated, I struggle to maintain community contacts and I work as a tutor. In the community, most of my employment has been as a fitness trainer ${ }^{7}$ and I would like to complete 
more post-secondary education, when my journey is not so fractured. I share my toughest learning experiences, in restorative justice contexts, with atrisk youth, schools, and universities. After participating in a Victim Impact Program, in 2013, I nervously accepted an invitation to meet with victims of crime in a Restorative Justice Initiative. Victims inspired my healing by gracing the experience with forgiveness, love, and understanding. I look forward to restorative justice opportunities in the future.

Near the two-year mark of my parole revocation, I feel desperate to return to the community, but I am at the mercy of an indifferent CSC authority. Familiar personal challenges are within view, as I daydream of a stable and healthy place, among loved ones, grateful for help from compassionate supports along the way. ${ }^{8}$ As it stands, my current institutional parole officer hesitates to support any conditional release until I "gain more insight" into my use of alcohol or, as she said, "until a light goes on". She is right about one thing; it is dark in here.

\section{ENDNOTES}

1 My experience is not unique in this regard. I encourage readers to review Volume 25(2) of the Journal of Prisoners on Prison, wherein my fellow prisoners discuss education in prison.

2 Gladiator School is used to connote a place where individuals had to learn to fight to survive.

3 Recent provisions of PTSD benefits to correctional employees reflect excessive institutional stress that was as prevalent as ever, thirty years ago.

4 I am responsible for a DUI, eight years ago, in 2011. On Canada Day long-weekend, I was pulled over, blew over, and pled guilty. I received a seven-day sentence, and my parole was revoked for two years. Returning to the community, I completed the Back-On-Track community-based treatment program. I learned more about the dangers of impaired driving and many alternatives to it. With this updated frame of reference, eight years later, I have not, and will not ever make the mistake of drinking and driving again.

5 A side-effect of this lack of resources is that it encourages prisoners to exaggerate problems to get counseling.

6 During my initial court proceedings in 1989, court appointed psychologists diagnosed me with unresolved trauma: on a camping trip, at four years old, I watched my sixyear-old brother fall into a river and drown. In 1976, skepticism for psychology delayed treatment until my offence brought the issue to bear. In counselling, I learned that much of my youth was spent aimlessly avoiding adolescent emotions, feelings enflamed by negative internal dialogue produced by the lingering trauma that, as a child, I lacked the language to express. Confronting my offence participation raised 
an awareness to my affected emotional development and subsequent failure to respect a community, with whom I was struggling to connect. Years of ensuing counselling and mindful reflection has taught me to recognize and challenge unhelpful thinking patterns, ameliorating internal struggles and opening my heart to connect with others more deeply. Eventually, this inspired my Personal Fitness Training career as a practical way to help others, creating meaningful opportunities to repent for my offence participation. Helping others has been a wind in my sails, ever since, a healthy platform on which to build positive relationships.

7 This was one of three post-secondary credentials earned in prison, along with a Construction Management Certification from St. Lawrence College (2014), and a Cook's Diploma from Liaison College (2009).

8 I cannot make it alone. I welcome as much community and professional support as I can get. Please share my writing freely as I need all the help I can get. My supports and I feel the overwhelming weight of this experience.

\section{REFERENCES}

Bales, William and Daniel Mears (2008) "Inmate Social Ties and the Transition to Society: Does Visitation Reduce Recidivism?", Journal of Research in Crime and Delinquency, 45: 287-321.

Clark, Robert (2017) Down Inside: Thirty Years in Canada's Prison Service, Fredericton: Goose Lane Editions.

Correctional Service Canada [CSC] (2017) Annual Report on Deaths in Custody 20162017, Ottawa. Retrieved from: https://www.csc-cc.gc.ca/005/008/005008-3013-en. shtml\#9.1

Corrections and Conditional Release Act, SC 1992, c. 20, s. 28 [CCRA]. Corrections and Conditional Release Regulations, Doc. SOR/92-620 (1992).

De Claire, Karen and Louise Dixon (2017) "The Effects of Prison Visits From Family Members on Prisoners' Well-Being, Prison Rule Breaking, and Recidivism: A Review of Research Since 1991", Trauma, Violence, \& Abuse, 18(2): 185-199.

Dixey, Rachael and James Woodall (2012) "The Significance of "The Visit" in an English Category B Prison: Views from Prisoners, Prisoners' Families and Prison Staff", Community Work and Family, 15: 29-47.

Health Canada (2018) Canadian Tobacco Alcohol and Drugs Survey (CTADS): 2017 Supplementary Tables, Ottawa.

Jewkes, Yvonne (2005) "Loss, Liminality and the Life Sentence: Managing Identity through a Disrupted Lifecourse", in Alison Liebling and Shadd Maruna (eds.), The Effects of Imprisonment, Portland (OR): Willan, pp. 366-390.

Maurutto, Paula and Kelly Hannah-Moffat (2006) "Assembling Risk and the Restructuring of Penal Control”, British Journal of Criminology, 46(3): 438-454.

Monahan, Kathryn, Asha Goldweber and Elizabeth Cauffman (2011) "The Effects of Visitation on Incarcerated Juvenile Offenders: How Contact with the Outside Impacts Adjustment on the Inside", Law and Human Behavior, 35: 143-151.

Munn, Melissa and Chris Bruckert (2014) On the Outside: From Lengthy Imprisonment to Lasting Freedom, Vancouver: UBC Press. 
Journal of Prisoners on Prisons, Volume 30(1), 2022

Office of the Correctional Investigator (2011) Deaths in Custody, Ottawa. Retrieved from: https://www.oci-bec.gc.ca/cnt/priorities-priorites/deaths-deces-eng.aspx

Office of the Correctional Investigator (1996) Annual Report 1995/96, Ottawa.

Parkes, Debra (2017) "Solitary Confinement, Prisoner Litigation, and the Possibility of a Prison Abolitionist Lawyering Ethic", Canadian Journal of Law and Society, 32(2): 165-185.

Public Safety Canada (2019) Corrections and Conditional Release Statistical Overview, Ottawa.

Sapers, Howard (2008) A Preventable Death. Ottawa: Office of the Correctional Investigator of Canada. Retrieved from: https://www.oci-bec.gc.ca/cnt/rpt/pdf/othaut/oth-aut20080620-eng.pdf

White, Patrick (2019) “Adam Capay's 1,647 days in solitary: New details emerge as Ontario decides not to appeal stay of murder charge", Globe and Mail - February 25. Retrieved from: https://www.theglobeandmail.com/canada/article-ontario-willnot-appeal-decision-to-abandon-murder-charge-against-adam/

Wildeman, Sheila (2020) "Disabling Solitary: An Anti-Carceral Critique of Canada's Solitary Confinement Litigation", in Claire Spivakovsky, Linda Steel and Penelope Weller (eds.), The Legacies of Institutionalisation: Disability, Law and Policy in the 'Deinstitutionalised' Community, Oxford: Hart.

\title{
ABOUT THE AUTHOR
}

James Ruston is serving a life sentence for an offence he committed when he was a minor and is now a member of the Toronto Prisoners' Rights Project. He was recently reincarcerated, initially in a provincial detention centre awaiting a parole revocation hearing and now at a federal penitentiary following a parole revocation for a technical breach of his parole conditions related to substance use. Messages can be sent to James via email at torontoprisonersrights@gmail.com or by mail at:

\author{
James Ruston \\ c/o Toronto Prisoners' Rights Project \\ PO BOX 291 Toronto P \\ Toronto, Ontario, Canada \\ M5B 2S8
}

